\title{
Naegeli-Franceschetti-Jadassohn syndrome
}

INSERM

\section{Source}

INSERM. (1999). Orphanet: an online rare disease and orphan drug data base. NaegeliFranceschetti-Jadassohn syndrome. ORPHA:69087

Naegeli-Franceschetti-Jadassohn (NFJ) syndrome is a rare ectodermal dysplasia that affects the skin, sweat glands, nails, and teeth. 